\title{
Freedom of Expression: Finding a Balance between Two Extremes
}

\author{
Dr. Sonya Shami ${ }^{*}$ \\ $\mathrm{PhD}$ in Foundations of Education, MA in Islamic Studies, Amman, Jordan. \\ * E-mail of the corresponding author: sonyashami@yahoo.com
}

\begin{abstract}
This study deals with the concept of freedom of expression in the West and compares it with its concept in Islam. It also examines some aspects of the practical application of this right, whether in the West or in Muslim countries, and the foundations on which it is applied, and the means by which it is expressed, giving examples of modern practices and allegations which either support this right or demolish it. This research aims to discuss the two extremes of freedom of expression, as well as the opposing parties, and the conditions and criteria that apply on the basis of security measures to restrict or control or adjust or prosecute. Finally this research seeks to find a balance between the two extremes, which draws features from the Islamic religion, and emphasizes the need to deduct the most important Divine foundations to ensure justice and security for all.
\end{abstract}

Keywords: Freedom of Expression, Balance, Islam, Extremes, Freedom of Speech, Coexistence.

DOI: $10.7176 / \mathrm{IAGS} / 88-04$

Publication date: December $31^{\text {st }} 2020$

\section{Introduction}

Moderation is the main feature of Islam. Extremes of any kind are in no way representative of Islam, and are certainly harmful for all people anywhere on earth. Human rights require true moderation, equality and justice.

This study aims to find the balance between two extremes which are on the opposite sides of the scale of freedom of expression. Some have too much freedom, others don't have enough. Controversy and debate have spread out in the world today regarding freedom of expression, emphasizing the need for a balanced and fair solution.

Islam offers the balance, and sets the boundaries and regulations which clarify ambiguous concepts regarding expression and the extent of freedom needed to implement it.

\section{Definition}

Expression means a particular way of phrasing or communicating a message. It can be spoken, written, graphic, straightforward, symbolic or mysterious. The term 'Freedom of Expression' is a legal term known internationally as one of the Human Rights. 'Freedom of Speech' is the most basic component of Freedom of Expression, and is a more commonly used term.

The Freedom Forum Institute (2020) defines Freedom of Expression as "the ability of an individual or group of individuals to express their beliefs, thoughts, ideas, and emotions about different issues free from government censorship. The First Amendment of the U.S. Constitution protects the rights of individuals to freedom of religion, speech, press, petition, and assembly. Some scholars group several of those freedoms under the general term "freedom of expression". The Universal Declaration of Human Rights, article 19 states that: "Everyone has the right to freedom of opinion and expression; this right includes freedom to hold opinions without interference and to seek, receive and impart information and ideas through any media and regardless of frontiers."

Siddiq (2010) however, clarifies the "according to Western legal standards, freedom of expression or speech means the absence of restraint upon the ability of individuals or groups to communicate their ideas to others, subject to the understanding that they do not in turn coerce others intAs self-reliant units, holons have a degree of independence and handle circumstances and problems on their particular levels of existence without reaching higher level holons for assistance. The self-reliant characteristic ensures that holons are stable, able to survive disturbances. 


\section{Types of Expression}

Expressing thoughts, ideas, beliefs, opinions, and emotions may be conveyed through different channels of communications, such as:

3.1 Linguistically through words and language, verbal speech (whether spoken or written).

3.2 Non-verbally through body language and facial expression.

3.3 Artistically through art, music, design, and fashion.

3.4 Spiritually through religion, rituals, and ceremonies.

3.5 Technologically through internet, radio, television, video games and other mediums.

Degrees of expression may vary from direct to obscure, from true to false, and from positive to negative. Culture and values play an important role in the choice of means and extent of expressing one's thoughts.

Next we will study the two major extremes concerning the right to freedom of expression which are seemingly creating unbalanced and opposite opinions in the world today, as well as creating controversy and having a negative influence on pluralism, cross-cultural and intercultural communications, and inter-faith dialogues worldwide.

\section{First Extreme (Limited Freedom)}

What is meant by limited freedom is to have restrictions upon the freedom of expression by authoritative figures. These restrictions may be imposed as reactionary measures to current events or as preventive measures to predictable events. Political, economic or religious affairs may be the main reasons for such limitations. Some restrictions may be necessary for national security; others may be unjust and may have negative consequences on the country and the rights of its people.

The term 'limited freedom' should not be mistaken for 'regulated freedom'. While the first is a violation of human rights, the latter is a guarantee of their application by eliminating any obstructions to full human dignity.

\subsection{Forms of Limited Freedom of Expression:}

Censorship is the most common form of limitation on freedom of expression. In normal circumstances, legitimate censorship occurs for a variety of reasons including national security, to control obscenity, child pornography, and hate speech, to protect children, to promote or restrict political or religious views, to prevent slander and libel, and to protect intellectual property.

Censorship methods include (but are not limited to): Broadcast or Publication delay, Internet Police, Content Control, Internet Censorship, Restriction, Website Blocking, Self-Censorship, etc.

Consequences vary according to the type and degree of censorship. In the Human Rights and Business Dilemmas Forum it was argued that "some companies are facing growing pressure from restrictive and repressive governments to limit freedom of expression in ways that might damage profitability."

\subsection{Examples of Limited Freedom of Expression:}

4.2.1 Google announces its withdrawal from China due to limits on free speech (Human Rights and Business Dilemmas Forum).

4.2.2 Users of the social network Twitter are censored in China and Iran (Human Rights and Business Dilemmas Forum).

4.2.3 First Reaction of repressive governments is Internet Censorship.

4.2.4 Jordanian Department of Press and Publications issues new laws restricting freedom of online expression.

To elaborate a little on the Jordanian example above, Human Rights Watch described the new Jordanian law as a threat to freedom of expression. "The dangers the proposed law poses to online expression arise from its vague definition of "electronic publications" that would be subject to the law, new executive power to block websites, and unreasonable restrictions on online content, including comments posted by website users, Human Rights Watch said.

Requiring bloggers, human rights activists writing on their websites, or other internet-based information dissemination to obtain licenses would put undue burdens on their freedom of expression, and the content restrictions on criminal defamation as well as user comments fail to meet the criteria of permissible restrictions, Human Rights Watch said. 
Jordan's existing Press and Publications Law, in articles 5, 7, and 38, and the penal code, in articles 122 and 188 to 200, among others, contain numerous content restrictions, criminalizing defamation including libel and slander, including against entities that are not people such as government institutions, symbols, and religions. These laws make violations a criminal offense carrying prison terms, contrary to recent definitive guidance on the right to freedom of expression by the UN Human Rights Committee, in its 2011 General Comment No 34. The committee (2012) wrote that, "States parties should consider the decriminalization of defamation and, in any case, the application of the criminal law should only be countenanced in the most serious of cases [of defamation] and imprisonment is never an appropriate penalty."

In an act of protest, hundreds of Jordanian websites went dark (calling it a 'BlackoutJo' protest), and posted this message: "You may be deprived of the content of this site under the amendments of the Jordanian Press and Publications Law and the governmental Internet censorship." (DeFraia, 2012)

7oryanet, a website promoting free internet and freedom of online expression, claimed that the new law will have the following consequences:

- Censorship: "The law allows the head of Press and Publications to block any international website that is in violation with the law. This means non-Jordanian sites can be blocked for any reason."

- Limiting freedom of speech: "The law also Censors and monitors your comments, which will be monitored and censored! Website owners will be responsible for the comments posted by citizens, thus having to censor user comments themselves. They also have to store all comments for a period of at least 6 months."

- Ambiguous: "The provisions of the law are very ambiguous, it states online media, which could include based on the government's discretion: social networks, photo and video sharing sites, blogs and more."

- Restrictive: "The law puts a lot of limitations on websites, which Disturbs freedom of speech, not only does it force websites to register and become members of the press association, appoint a chief editor, and pay membership fees, it allows courts to prosecute any website." (DeFraia, 2012)

\section{3 reasons for Limited Freedom of Expression:}

Kai (n.d) explains that "most countries of the Middle East and Islamic world are entering the 21st century without any considerable degree of freedom of speech and media freedom. The number of TV and radio channels has grown due to the massive spread of satellite technology. However, with a few exceptions (e.g. Aljazeera TV in Qatar) there is no clearly conceivable move towards media liberalization. On the contrary, in some countries liberalization has suffered from retrogressive authorization policies. More than the West, governments functionalize the media whenever they want to activate or deactivate negative images of the West."

The most obvious reason is that some governments have used the rationale of 'national security' in order to stifle political opposition, activism and other forms of criticism (Human Rights and Business Dilemmas Forum).

\section{Second Extreme}

What is meant by unlimited freedom of Expression, is that which exceeds boundaries of moral expression, and subjects the audience to deceitful, immoral, offensive, distorted, wrong and/or unjust information concerning a third party.

This kind of extreme is internationally labeled as illegal, although in many cases and in many countries, such violations have been taken lightly, disregarded all together, or considered protected by law as a form of freedom of speech. The reason for such contradiction is due to the fact that even though definitions of different kinds of malicious expressions are described in constitutions, there is a fine line between what is considered prohibited and threatening and what is considered allowed and harmless.

This kind of contradiction and distinguish is apparent when such violations are conducted against the religion of Islam, its Prophet (peace be upon him), or Muslims. Many Western Countries continue to show double standards in dealing with Media contents or other means of expression. Some would choose to neglect and even defend offensive material to Islam and Muslims, while at the same time criminalizing and applying strict laws against other offenses concerning other religions, such as the denial of the Jewish Holocaust for example. Next I will discuss the forms and methods of this kind of extreme as well as some recent examples showing how far it has been implemented, and briefly study the reasons for such violations. 
5.1 Forms of Unlimited Freedom of Expression:

Generally speaking, there are two main forms of unlimited freedom of expression:

\subsubsection{Direct:}

This is a plain, straightforward, and unambiguous form of expression which bears negative meanings toward a person, group, religion, race, etc. and openly promotes prejudice and hatred. Defamation, which includes libel and slander, is one kind of 'hate speech'. Adult 'Entertainment', namely pornography (written, pictured or filmed), also falls under this category, although in many countries the 'right' to pornography is protected by the constitution (obscenity and child pornography however are not). Expressive conduct and symbolic acts do fall under this category if they candidly convey a negative message (like burning flags or wearing expressive T-shirts or carrying banners for instance). (Willingham, 2012)

\subsubsection{Indirect:}

Media outlets have certain ways to indirectly but purposefully manipulate information in order to control the ways people absorb the intended message, and direct their ideologies toward a certain perspective. Dr. Ahmad Ibn Rashid Said, professor of Journalism and political communication at King Saud University and an expert in discourse analysis, summarizes some of these ways as follows: (Said, 2012)

- Euphemism: the substitution of an agreeable or inoffensive expression for one that may offend or suggest something unpleasant. E.g.: using "eliminate" as a euphemism for "kill" (Merriam Webster Dictionary).

- Framing: to contrive the evidence against (an innocent person(s)) so that a verdict of guilty is assured (Merriam Webster Dictionary).

- Name Calling / Connotation: the suggesting of a meaning by a word apart from the thing it explicitly names or describes (Merriam Webster Dictionary).

- Negative Lexicalization: the selection of (strongly) negative words to describe the actions of the others. E.g.: "terrorism", "extremism", etc (Van Dijk).

- Card Staking: showing perspectives of one party and neglecting to show the perspective of the other party.

- Presupposition: A well-known semantic device to indirectly emphasize our good properties and their bad ones is presupposition. That is, these properties are simply assumed to be known, as if they were common sense, and hence need not be specifically asserted (Van Dijk).

However, it is important to stress the fact that some of these acts (mostly the direct type) are labeled as illegal in international laws under the 'freedom of speech' articles. In the United States Constitution for example, we do find such criteria.

According to the United States Constitution (2020), defamation means: "Any statement, whether written or oral, that injures a third party's reputation." Defamation includes both libel and slander. "To establish a prima facie case of defamation, four elements are generally required:

- A false statement purporting to be fact concerning another person or entity

- Publication or communication of that statement to a third person;

- Fault on the part of the person making the statement amounting to intent or at least negligence

- Some harm caused to the person or entity who is the subject of the statement."

Also the Constitution states that "Libel is a method of defamation expressed by print, writing, pictures, signs, effigies, or any communication embodied in physical form that is injurious to a person's reputation, exposes a person to public hatred, contempt or ridicule, or injures a person in his/her business or profession." According to American law, speech that defames, endangers or incites to violence is prohibited. Hate speech is not banned unless it is a direct threat to others.

\subsection{Examples of Unlimited Freedom of Expression:}

5.2.1 False accusations made against Islam by Non-Muslims and some Westernized Secular Muslims (E.g. the claim that women have no rights in Islam, and that Muslims are terrorists).

5.2.2 Anti-Islamic films. E.g. a pornographic film called "The Sex Life of the Prophet Muhammad," A film called "Innocence of Muslims," a short film called "Fitna," a short film called "Submission," and many more 
(Raving Atheist, 2002).

5.2.3 Anti-Islamic Cartoons. E.g. Danish Cartoons, French magazine cartoons, South Park, Imran Firasat cartoons, And many more. (Abdulla at al, 2020)

5.2.4 Anti-Islamic Publications E.g. Salman Rushdie's "Satanic Verses," Imran Firasat's "Prophet Muhammad Illustrated", and many more (Prophet Muhammad Illustrated).

All of these examples and many more continue to stir controversy and debate over freedom of expression. Dr. Christensen of Uppsala University states that "the right to freedom of speech equates to neither an obligation to offend nor a duty to be insensitive. There is no contradiction between supporting someone's right to do something and condemning them for doing it. If our commitment to free speech is important, our belief in antiracism should be no less so." (Christensen, 2012)

The Guardian reported: "In the Midst of this tinderbox, insisting on their right to speak freely and with the support of many Dutch people, Hirsi Ali and Van Gogh [writer and producer of the film 'Oppression'] scattered their sparks a blistering critique of Islam with magnificent disregard for the feelings they might be offending." (Quraishy, 2006)

"This general description of Islam as a religion or faith is very insulting, derogatory and provocative to most Muslim communities. They welcome criticism of individuals, groups or even whole societies, where Islam is the major religion but draws the line between 'Freedom of Speech' and 'Freedom of Hate Speech'.” (Quraishy, 2006)

It is important to point out that the outrage by Muslims around the world regarding these insults and their way of protesting most of these works and many others had ranged in method from peaceful protests and efforts of interfaith dialogues, to violent and un-Islamic clashes, leading in some cases to deaths and injuries. These violent clashes had been and continue to be used as 'proof' of the accusations made against Islam and Muslims in most of these works. "The Western media has failed to report the struggle between good and bad, tolerance and intolerance, orthodox and moderate that goes on within Islam a well as around it. The efforts of liberals in Islamic communities world over, are not helped by the tendency of non Muslims to behave as if the only voices of Islam that mattered, were of the reactionaries." (Quraishy, 2006)

\subsection{Reasons for Unlimited Freedom of Expression:}

The Prophet (peace be upon him) said: "One of the things people have learned from the words of the earliest prophecy is: If you have no shame, do what you like." (Abu Dawud)

Unlimited freedom, secularism, and indifference lead to shameless acts in the name of freedom and human rights. Other reasons include:

- Ignorance

- Ethnocentric educational system

- Deadline pressure from management of media outlet

- Editorial interference

- Economic interest of employees

- Competition

- Cultural ignorance

- Cultural arrogance

- Lack of quick and effective response from victims of media manipulations

- Lack of coordination among Muslim communities (Quraishy, 2006)

It is a one-sided war of information, based on manipulation, deception and betrayal of the public interest (Said, 2012).

\section{Finding a Balance}

God Al-Mighty says to Muslims in His Holy Book: (And thus we have made you a just community that you will be witnesses over the people and the Messenger will be a witness over you) (Quran 2:143)

Islam as a religion and a way of life is fit for all times and places. When practiced right, Islam solves all problems, big or small. The following will prove that Islam is a religion of moderation, justice and balance. The 
right application of Islam ensures the fulfillment of human rights and the termination of all kinds of extremes.

\subsection{Freedom of Expression in Islam:}

In Islam, all people have the right to express themselves. All people have the right to think, form opinions, believe in any religion, and express thoughts and feelings. However, there are certain principles and regulations; laws that guide and prescribe the conduct of individuals. The reason for such regulations is that the right to expression is inter-related with other human rights such as the right to dignity, the right to equality, and the right to free will and freedom of belief. Freedom of expression is a right, as long as it is within the frame of morality. Any conduct that disrupts other human rights is considered no longer a freedom but rather a violation of the right to expression and a sin. Siddiq (2010) explains "In Islam, freedom of expression is restrained only where the failure to do so would result in harming the cause of truth." He also says "Evil speech interferes with the discovery of truth and thus violates human dignity."

To illustrate these regulations, we need to distinguish between the two categories of these regulations, the "Do's" and the "Don'ts", The "Ethical Requirements" and the "prohibitions" which together regulate the right to Freedom of Expression and create a fair balance between the extremes mentioned earlier in this study, as well as assure the dignity and equality of all humans, regardless of religion or nationality or race.

First I will mention some Quranic Verses and Prophetic sayings (hadith), then I will derive from them a list of requirements and prohibitions regarding freedom of expression.

God says in the Holy Quran:

(Say, "Produce your proof, if you should be truthful.") (Quran 2:111)

(And the one who has brought the truth and [they who] believed in it - those are the righteous) (Quran 39:33)

(Invite to the way of your Lord with wisdom and good instruction, and argue with them in a way that is best. Indeed, your Lord is most knowing of who has strayed from His way, and He is most knowing of who is [rightly] guided.) (Quran 16:125)

(And let there be [arising] from you a nation inviting to [all that is] good, enjoining what is right and forbidding what is wrong, and those will be the successful) (Quran 3:104).

(And speak to people good [words]) (Quran 2:83)

(And tell My servants to say that which is best. Indeed, Satan induces [dissension] among them. Indeed Satan is ever, to mankind, a clear enemy) (Quran 17:53)

(O you who have believed, fear Allah and speak words of appropriate justice) (Quran 33:70)

(O you who have believed, if there comes to you a disobedient one with information, investigate, lest you harm a people out of ignorance and become, over what you have done, regretful) (Quran 49:6)

(O you who have believed, let not a people ridicule [another] people; perhaps they may be better than them; nor let women ridicule [other] women; perhaps they may be better than them. And do not insult one another and do not call each other by [offensive] nicknames. Wretched is the name of disobedience after [one's] faith. And whoever does not repent - then it is those who are the wrongdoers * O you who have believed, avoid much [negative] assumption. Indeed, some assumption is sin. And do not spy or backbite each other. Would one of you like to eat the flesh of his brother when dead? You would detest it. And fear Allah; indeed, Allah is Accepting of repentance and Merciful.) (Quran 49: 11-12)

(Woe to every scorner and mocker) (Quran 104:1)

(And [they are] those who do not testify to falsehood, and when they pass near ill speech, they pass by with dignity) (Quran 25:72)

(And do not obey every worthless habitual swearer * [And] scorner, going about with malicious gossip - * A preventer of good, transgressing and sinful, * Cruel, moreover, and an illegitimate pretender) (Quran 68: 10-13)

(So by mercy from Allah, [O Muhammad], you were lenient with them. And if you had been rude [in speech] and harsh in heart, they would have disbanded from about you) (Quran 3:159)

(And do not argue with the People of the Scripture except in a way that is best, except for those who commit injustice among them, and say, "We believe in that which has been revealed to us and revealed to you. And our God and your God is one; and we are Muslims [in submission] to Him.") (Quran 29:47) 
(And you will surely hear from those who were given the Scripture before you and from those who associate others with Allah much abuse. But if you are patient and fear Allah - indeed, that is of the matters [worthy] of determination.) (Quran 3:186)

(Say, "O People of the Scripture, come to a word that is equitable between us and you - that we will not worship except Allah and not associate anything with Him and not take one another as lords instead of Allah." But if they turn away, then say, "Bear witness that we are Muslims [submitting to Him].") (Quran 3:64)

(Indeed, those who abuse Allah and His Messenger - Allah has cursed them in this world and the Hereafter and prepared for them a humiliating punishment * And those who harm believing men and believing women for [something] other than what they have earned have certainly born upon themselves a slander and manifest sin) (Quran 33:57-58)

(And when they hear ill speech, they turn away from it and say, "For us are our deeds, and for you are your deeds. Peace will be upon you; we seek not the ignorant.") (Quran 28:55)

(And not equal are the good deed and the bad. Repel [evil] by that [deed] which is better; and thereupon the one whom between you and him is enmity [will become] as though he was a devoted friend) (Quran 41:34)

(..and who restrain anger and who pardon the people - and Allah loves the doers of good) (Quran 3:134)

\subsubsection{Ethical Requirements:}

When studying the ethical requirements set by Islam in terms of freedom of expression, it must be noted that applying such ethics are obligatory to every Muslim. The failure to do so however may not have preset worldly punishments, but it certainly does have negative social consequences, and a person may be deprived of great rewards in the hereafter. It is strongly advised that Muslims do the requirements so as to guarantee a stable and healthy social life and many great rewards in the hereafter.

According to the previous verses, these ethical requirements are as follows:

- $\quad$ Truth

- Honesty

- Wisdom

- $\quad$ Good instruction

- $\quad$ Good and worthy argumentations

- Dialogue

- Enjoining what is right

- $\quad$ Forbidding what is wrong

- $\quad$ Good words

- Appropriate justice

- $\quad$ Leniency and kindness

- Investigating truth of news and information before making judgments

- Advice

- Counselling / consultation

- $\quad$ Listening to the other party

- Patience

- $\quad$ Restraining and controlling anger

- Pardoning

- Doing good to all people, including those who are ignorant

- Turning away from ill-speech

6.1.2 Prohibitions:

In Islam, there are no set worldly punishments for the following prohibitions except for forgery and accusing someone of adultery without having witnesses. All of these prohibitions however are considered sinful and are punished for in the hereafter, unless the person repents. The list of prohibited speech and expression as 
mentioned in the verses above are:

\begin{tabular}{ll} 
- & Ill-speech \\
- & Ridicule \\
- & Mockery \\
- & Insult \\
- & Name calling \\
- & Backbiting \\
- & Malicious gossip \\
- & Spying \\
- & Lying \\
- & Slander \\
- & Fabrication / framing \\
- & Forgery \\
- & Accusation of chaste persons \\
- & Negative assumptions \\
- & Worthless argumentation \\
- & Scorning \\
- & Transgressing \\
- & Rudeness \\
- & Harshness \\
- & Blasphemy \\
- & Cursing \\
- & Habitual worthless swearing \\
- & Biased / prejudiced speech \\
- & Hate speech \\
- & Threats \\
\hline
\end{tabular}

The Prophet (peace be upon him) said: "Anybody who believes in Allah and the Last Day should talk what is good or keep quiet." [i.e. abstain from all kinds of evil and dirty talk]. (Al-Bukhari)

\subsection{Islamic Way of Dealing with the Two Extremes:}

In the normal circumstances, Muslims have the right and freedom to express themselves within Islamic terms and regulations, moral boundaries and Sharīa ah law. No one has the right to obstruct or restrict that freedom (unless under severe circumstances and utmost necessity), and no one has the right to use express evil or negative messages in order to defame or harm another individual or religion.

The prophet (peace be upon him) said: "Whoever among you sees an evil, let him change it with his hand; if he cannot, then with his tongue; if he cannot, then with his heart- and that is the weakest of Faith." (Al-Nasai) Thus stressing that a Muslim has the right to express his/her disapproval with evil deeds or speech, and tyranny of all kind. But even in doing so, a Muslim should express his/her disapproval by explaining the wrong and giving solutions, being positive and try to make a change, and behave in the best way possible.

If faced by the other extreme, Muslims should stay calm and not use violence. They should refer to dialogue and educate. They should stick to the truth and be wise and give their best argument.

The Prophet (peace be upon him) said: ""The Muslim is the one from whose tongue and hand the people are safe, and the believer is the one from whom the people's lives and wealth are safe." (Al-Nasai)

He also said: "The strong is not the one who overcomes the people by his strength, but the strong is the one who controls himself while in anger." (Al-Bukhari)

"Blasphemy in Islam is defined nowadays as contemptuous hostile statements against either the fundamentals of 
Islam, against Allah, the personality of the Holy Prophet (saw), or any other prophet or anything sacred in Islam, such statements being made with the intention to offend the sensibilities of Muslims. The Arabic word for blasphemy is sabb (insult). Although blasphemy is considered an offence in Islam, either committed by a Muslim or a non-Muslim, no punishment is prescribed for it in the Holy Qur'an. Rather, the punishment for it is always in the hands of God alone, to be meted out by Him either in this life or in the Hereafter." (Siddiq, 2010)

\section{Conclusion:}

God says: (You are the best nation produced [as an example] for mankind. You enjoin what is right and forbid what is wrong and believe in Allah) (Quran 3:110)

This verse clearly states that as long as we enjoin what is right and forbid what is wrong, we will be the best nation among the nations of the earth and justice will prevail. However, because we have failed to do that, we see so much evil and hate going on in the world today.

"Selective and therefore biased analysis adds to our ignorance rather than our knowledge, narrows our perspective rather than broadening our understanding, reinforce the problem rather than opening the way to new solutions." (Shadid, 2002)

Moderation is what creates balance. Islam has the moderation needed to create that sort of balance in the world and eliminate all kinds of extremes, so that justice, happiness, peace, coexistence and mercy would prevail.

\section{References}

Abdulla, N., Sahinkaya, E., Jedinia, M., Noorzai, R. (2020), Why Depicting Prophet Muhammad Is Controversial in Islam?, Extremism Watch, retrieved on 25/11/2020 from https://www.voanews.com/extremism-watch/why-depicting-prophet-muhammad-controversial-islam

Abu Dawud, Sulayman Ibn al-Ashath. Sunan Abi Dawud. Book 1-26. Translated by: www.sunnah.com . 2012. Powered by the Apache Lucene Search Engine http://ucene.apache.org/ (with differences in the numbering scheme in English and Arabic Hadiths).

Al-Bukhari, Abu Abdullah Muhammad Ibn Ismail. Șaḥiḥ al-Bukhari. Vol. 1-9. Translated by: www.sunnah.com. 2012. Powered by the Apache Lucene Search Engine http://lucene.apache.org/ (with differences in the numbering scheme in English and Arabic Hadiths).

Al-Nasai, Ahmad Ibn Shuayb. Sunan al-Nasai, Vol.2-6. Translated by: www.sunnah.com. 2012. Powered by the Apache Lucene Search Engine http://lucene.apache.org/ (with differences in the numbering scheme in English and Arabic Hadiths).

Christensen, Christian. Islam and the Media: cartoons and Context. Australian Media Literacy. 2012.

DeFraia, Daniel (2012). Jordan: Internet Blackout Protests Censorship. Global Post. www.globalpost.com

Freedom Forum Institute (2020), What is Freedom of Expression. Retrieved 25/11/2020 from https://www.freedomforuminstitute.org/about/faq/what-is-freedom-of-expression/

Holy Quran. Ayat, Desktop Version No. 1.1.0 of KSU Electronic Holy Quran Project. Developed by the ETC at King Saud University. Quran Images Files Printed by: King Fahd Complex. Source of Quran text and Translations: www.tanzil.net. Source of Explanations: www.mosshaf.com. Downloaded from: http://quran.ksu.edu.sa/ayat/?1=en.

http://en.wikipedia.org/wiki/Innocence_of_Muslims

http://en.wikipedia.org/wiki/Fitna_(film)

http://en.wikipedia.org/wiki/Submission_(2004_film)

http://en.wikipedia.org/wiki/Danish_cartoons

http://edition.cnn.com/2012/09/19/world/europe/france-mohammed-cartoon/index.html

http://theamericanmuslim.org/tam.php/features/articles/south_park_episode

http://mundosinislam.com/

http://prophetmuhammadillustrated.com/

Human Rights Watch. Jordan: A Move to Sensor Online Expression. 2012. 
http://www.hrw.org/news/2012/09/10/jordan-move-censor-online-expression

Kai, Hafez (n.d). The West and Islam in the Mass Media: Cornerstones for a New International Culture of Communication in the 21 st Century.

Merriam Webster Online Dictionary. http://www.merriam-webster.com/

Quraishy, Bashy. Islamic Images and Terminology used in the Western Media. Brussels Talks Round Table: Islamophobia in the Media. Belgium. 2006.

Raving Atheist. Texas Muslims Protest X-Rated Film Defaming Muhammad's XXX-Rated Sex Life. Retrieved on 25/5/2002 from www.ravingatheist.com

Said, Ahmad Ibn Rashed (2012). Mashru al-Arabiyah Net Huwa al-Tatbi ma al-Shudud. www.Almesryoon.com 2012.

Shadid, W. \& Koningsveld, P.S. The Negative Image of Islam and Muslims in the West: Causes and Solutions. Leuvan, Peeters. 2002.

Siddiq, Nadim Ahmad. Freedom of Conscience and Expression in Islam. www.reviewofreligions.org 2010.

The Global Compact. Human Rights and Business Dilemmas Forum. http://humanrights.unglobalcompact.org/dilemmas/freedom-speech

The universal Declaration of Human Rights. The United Nations. www.un.org

United States Constitution: First Amendment (2020). Legal Information Institute. Cornell University Law School. http://www.law.cornell.edu/wex/defamation

United States Constitution: First Amendment. Legal Information Institute. Cornell University Law School. http://www.law.cornell.edu/wex/libel

Van Dijk, Teun A. Ideological Discourse Analysis. University of Amsterdam. http://www.discourses.org/OldArticles/Ideological\%20discourse\%20analysis.pdf

Wikipedia Encyclopedia. Censorship. http://en.wikipedia.org/wiki/Censorship

Willingham, Theresa (2012). Understanding Types of Free Speech. http://suite101.com/article/understandingtypes-of-free-speech-a62509 